International Journal on Social Science, Economics and Art, 11 (4) (2022) 172-179

\title{
Analysis of The Effect of Non-Cash Payments, Interest Rate, and The Amount of The Money Circulation on Inflation in Indonesia
}

\author{
Ananda Putri' ${ }^{1}$, Safuridar $^{2}$, Suri Amilia ${ }^{3}$, Asnidar ${ }^{4}$ \\ 1,3 Development Economics Study Program, Samudra University, Langsa
}

\begin{tabular}{l}
\hline Article Info \\
\hline Article history: \\
Received: oct 21, 2021 \\
Revised: Jan o8, 2022 \\
Accepted: Feb 27, 2022 \\
\hline
\end{tabular}

\section{Keywords:}

Non-cash payments; Interest rates; Money supply; Inflation.

\begin{abstract}
This study aims to determine how the partial and simultaneous influence of non-cash payments, interest rates and the money supply on inflation in Indonesia. This research was carried out from January 2021 to June 2021. The type of research data is quantitative. The independent variables in this study are non-cash payments ( $\left.\mathrm{X}_{1}\right)$, interest rates $\left(\mathrm{X}_{2}\right)$, and the money supply $\left(\mathrm{X}_{3}\right)$ while the dependent variable is inflation $(\mathrm{Y})$ with the object of research in Indonesia. Sources of data were collected in the form of secondary data for the 2009-2019 time series obtained from Bank Indonesia and the Central Statistics Agency. The analytical method used is multiple linear regression and classical assumption test. The results of the study partially state that non-cash payments and the money supply do not affect inflation, while interest rates have a significant effect on inflation in Indonesia. Simultaneously non-cash payments, interest rates and the money supply have a significant effect on inflation in Indonesia. Score $R$ square is 0.4670 or $46.70 \%$, meaning that the variables of $e$-money, interest rates, and the money supply affect inflation in Indonesia by $46.70 \%$, while the remaining $53.30 \%$ is influenced by other factors outside the study.
\end{abstract}

This is an open access article under the CC BY-NC license.

\section{Corresponding Author:}

\section{Safuridar}

Development Economics Study Program,

Samudra University,

Jl. Prof. Dr. Syarief Thayeb, Meurandeh, Langsa City, Aceh 24416.

Email: safuridar@unsam.ac.id

\section{INTRODUCTION}

In every economic activity, daily economic actors certainly result in a transaction that accompanies these activities. The transactions that occur are of course closely related to the payment system. Bank Indonesia is a financial institution that has the power to control the payment system (Dagdemir \& Sauer, 2015)(Lindsey, 2012). With the help of technology that is growing rapidly, the payment system is always progressing from cash payments (cash-based) to non-cash payments (non-cash)(Xena \& Rahadi, 2019). Advances in payment instruments can shift the role of cash as a means of payment into non-cash payments that are more efficient and economical(Widjaja, 2016)(Harasim, 2016)(Hess, 2017). These non-cash payments cover a wide range of bases from card-based transactions to electronic network-based transactions (Mohammad, 2008)(Worthington \& Edwards, 2000). In its development, card-based non-cash payment instruments and electronic networks have different characteristics 
(Carl, 2017)(Dagdemir \& Sauer, 2015)(Putra et al., 2017). Electronic network-based non-cash payment systems are also known as electronic money (E-money) (Ningsih \& Kristiyanti, 2019).

For financial purposes, there are currently a lot of technologies that can be used, for example the development of e-money (Mentari et al., 2019). E-money facilitates and supports the needs of people's activities in many ways, such as paying tolls, general transactions such as buying credit and shopping (Setiawati \& Falah, 2019) (Davenport \& Short, 1990). Payments made using e-money do not always require an authorization process and are online with the customer's account at the bank (Williamson \& Money-America's, 2006) (Shamraev, 2019) (Widayat et al., 2020). In e-money, the value of money has been stored electronically in a payment instrument in the form of a media server or chip used (Abidin, 2015).

Provisions regarding e-money have been regulated in Bank Indonesia Regulation No.7/52/PBI/2005, however, these regulations are integrated with the regulations for the operation of card-based payment instruments (APMK) (Silitonga, 2013). The increase in public activity using this non-cash payment facility will be able to speed up transactions or in other words will affect the speed of change in money(Mentari et al., 2019).

Various studies on the correlation of e-money and the velocity of money show a positive relationship. This is following the explanation of (Priyatama \& Apriansah, 2010) that the increase in the use of e-money in Indonesia has an impact on increasing the speed of change in money. Another study conducted (Popovska-Kamnar, 2014) in various European countries also stated that with the use of e-money, transactions are relatively cheaper and allow an increase in the number of transactions and an increase in the velocity of money. The circulation of money can affect inflation when the velocity of money is high. This statement was also stated by Priyatama and Apriansah (2010) that the velocity of money circulation is one of the variables that determine inflation (Zunaitin, 2017).

To see the development of E-money and the amount of money in circulation in Indonesia in 2015-2019 can be seen in Table 1 as follows

Table 1. The Development of E-money and the Money Supply in Indonesia 2015-2019 Tahun

\begin{tabular}{ccccc}
\hline Year & $\begin{array}{c}\text { E-money } \\
\text { (Million Rupiah) }\end{array}$ & Growth (\%) & $\begin{array}{c}\text { JUB } \\
\text { (Billion Rupiah) }\end{array}$ & $\begin{array}{c}\text { Growth } \\
\text { (\%) }\end{array}$ \\
\hline 2015 & $34,314,795$ & - & $4,548,800$ & - \\
2016 & $51,204,580$ & 32.99 & $5,004,976$ & 9.11 \\
2017 & 90.003 .848 & 43.11 & $5,419,165$ & 7.64 \\
2018 & $167,205,578$ & 46,17 & $5,760.046$ & 5.92 \\
2019 & 292.299 .320 & 42.80 & $6,136,552$ & 6.14 \\
\hline \multicolumn{5}{c}{}
\end{tabular}

Table 1 shows that $e$-money and the money supply in Indonesia tend to experience various fluctuations. In 2015-2019 the development of e-money circulating in the community always increases every year, this is because the use of e-money is increasingly widespread in the community which makes it easier to make payment transactions, one of which is in the transportation sector and so on. Likewise, the money supply in 2015 to 2019, continued to experience a significant increase, due to the increasing demand for goods and services due to increased public income which made too much money circulating in the community.

As for seeing the development of interest rates and inflation in Indonesia, it can be seen in Table 2 as follows:

Table 2. Developments in Interest Rates and Inflation in Indonesia in 2015-2019

\begin{tabular}{ccc}
\hline Year & Interest Rate (\%) & Inflation (\%) \\
\hline 2015 & 7.50 & 3.35 \\
2016 & 4.75 & 3.02 \\
2017 & 4.25 & 3.61 \\
2018 & 6.00 & 3.13 \\
2019 & 5.00 & 2.72 \\
\hline Source: Bank Indonesia (BI) and the Central Statistics Agency (BPS) 2021
\end{tabular}


Based on table 2, shows that the highest interest rate was in 2015 at $7.50 \%$ and in 2017 it decreased by $4.25 \%$ due to the economic recovery at that time which caused Bank Indonesia to lower interest rates. Meanwhile, the inflation rate in 2017 increased by $6.61 \%$ which previously decreased in 2016 by $3.02 \%$. Then in 2019 it decreased by $2.72 \%$. This is because the production capacity is far more adequate than demand, as well as the relatively controlled prices of goods and food.

If a country wants to maintain a low inflation rate, of course the government must suppress price increases. This effort can be done by suppressing the rate of increase in the money supply, for example by limiting lending or by increasing loan interest rates.

Based on the explanation of the problems above, the researchers are interested in researching with the title "Analysis of the Effect of Non-Cash Payments, Interest Rates and the Amount of Money Supply on Inflation in Indonesia ". This study aims to determine the effect of non-cash payments, interest rates, and the money supply partially and simultaneously on inflation in Indonesia.

\section{RESEARCH METHOD}

Data Types and Data Sources, The type of data used in this study is quantitative data with data sources using secondary data in the form of time series obtained from Bank Indonesia (BI), the Central Statistics Agency (BPS), and scientific journals that support this research (Madani \& Widiastuti, 2021).

Method of collecting data, The data collection method used literature study by reading books and other literature, both required and recommended and related to the problems that will be discussed in this study (Vom Brocke et al., 2015) (Tellis, 1997) (Snyder, 2019). Meanwhile, documentation is done by collecting secondary data through official websites, such as Bank Indonesia (BI) www.bi.go.id and the Central Statistics Agency (BPS) www.bps.go.id with research objects in Indonesia.

Data analysis method, To analyze the research using the multiple linear regression analysis methods. According to (Sugiyono, 2011) multiple linear regression is based to determine the effect of the independent variable on the dependent variable. The multiple linear regression equation is:

$$
\begin{aligned}
\mathrm{Y}=\mathrm{a} & +\beta_{1} \mathrm{X}_{1}+\beta_{2} \mathrm{X}_{2}+\ldots . .+\beta_{\mathrm{n}} \mathrm{Xn}+\mathrm{e} \\
& \text { Where: } \\
\mathrm{Y} & =\text { dependent variable } \\
\mathrm{a} & =\text { constant } \\
\beta & =\text { regression coefficient } \\
\mathrm{X} & =\text { independent variable } \\
\mathrm{e} & =\text { error }
\end{aligned}
$$

testing is done by looking at the estimated t-test, $\mathrm{F}$ test, $\mathrm{R}^{2}$ and classical assumption test consisting of autocorrelation test, multicollinearity test, heteroscedasticity test, and normality test.

\section{RESULTS AND DISCUSSIONS \\ 3.1. Results \\ a. E-money development}

The development of e-money shows that from 2009 to 2013 it continued to increase. The reason for this is due to technological advances that are growing very rapidly. The existence of e-money provides convenience and security for the community, one of which is by not carrying cash for transactions. That way people are more comfortable and safe. This is what encourages people to use $e$ money.

In 2016 there was a fairly high increase of $49.22 \%$, this was due to the obligation to pay noncash tolls and the rapid development of online transactions. In 2020 the development of $e$ money users decreased from the previous year, which in 2019 amounted to $74.81 \%$ to $47.89 \%$, this is due to the existence of Large-Scale Social Restrictions (PSBB).

\section{b. Interest Rate Development}

Interest rate developments show that in 2009 the BI Rate was 6.50\%, this year Bank Indonesia lowered the BI Rate from the previous year by different amounts in three periods. In the first period (January- 
March 2009) it was at the level of 7.75\%, in the second period (April-August 2009) it was lowered to the level of $6.50 \%$. Meanwhile, in the third period (September-December 2009) it was maintained at the level of $6.50 \%$, due to the perceived stability of the financial system.

In 2017 the BI rate decreased by $4.25 \%$. This decline was carried out due to the room for easing monetary policy, which saw that the realization and forecast of inflation in 2017 and 2018 were within the specified target range. This decline is expected to strengthen banking intermediation, thereby strengthening financial system stability and supporting higher economic growth. Until 2020, Bank Indonesia set the BI Rate at 3.75\%.

\section{c. Development of the Money Supply}

The development of the money supply shows that the money supply in 2009-2020 always increases every year. This is because people are more willing to hold their own money. The greater the capacity of money provided by banks to the public, the more the money supply will increase. Because the price of an item increases so that the money supply will increase.

\section{d. Inflation Development}

Inflation shows that in 2009 inflation decreased by $2.78 \%$, lower than the inflation target set by the government of $4.50 \%$. This was due to the strengthening of the rupiah and the availability of supplies, specifically for foodstuffs, which had boosted the inflation rate.

In 2015 , the inflation rate was $3.35 \%$, a drastic decrease from inflation in 2014 of $8.36 \%$. The strengthening of coordination succeeded in maintaining smooth distribution and supply in the impact of El Nino to maintain price stability for volatile foods. Then in 2019, inflation showed a pretty good development, where this year's inflation was recorded as the lowest inflation in the last 20 years, at $2.72 \%$. This is due to production capacity that is far more adequate than demand, the exchange rate of the rupiah against the US dollar is quite stable, and the results of a survey on inflation estimates from various sectors have decreased, this is what makes inflation low.

\subsection{Discussion}

\section{a. Multiple Linear Regression Analysis}

Tabel 3. Multiple Linear Regression Analysis

\begin{tabular}{lrlrr}
\hline \hline \multicolumn{1}{c}{ Variable } & Coefficient & \multicolumn{1}{c}{ Std. Error } & t-Statistic & Prob. \\
\hline \multicolumn{1}{c}{ C } & -2.255285 & 1.504937 & -1.498591 & 0.2083 \\
LOGX1 & 0.169052 & 0.322439 & 0.524290 & 0.6278 \\
LOGX2 & 1.202423 & 0.738341 & 1.628548 & 0.1787 \\
\multicolumn{1}{c}{ LOGX3 } & 0.366698 & 0.332831 & 1.101753 & 0.3324 \\
\hline \hline R-squared & 0.695481 & Mean dependent var & 1.423455 \\
Adjusted R-squared & 0.467091 & S.D. dependent var & 0.405183 \\
S.E. of regression & 0.295786 & Akaike info criterion & 0.708493 \\
Sum squared resid & 0.349958 & Schwarz criterion & 0.748214 \\
Log likelihood & 1.166026 & Hannan-Quinn criter. & 0.440593 \\
F-statistic & 3.045151 & Durbin-Watson stat & 2.353796 \\
Prob(F-statistic) & 0.155069 & & \\
\hline \hline
\end{tabular}

Source: Data processed with Eviews 10, 2021

Based on the table above, multiple linear regression equations can be made as follows:

$\mathrm{Y}=-2,255.285+0,1690 \mathrm{X}_{1}+1,2024 \mathrm{X}_{2}+0,3666 \mathrm{X}_{3}+\mathrm{e}$

From this equation, it can be interpreted as follows:

a) The constant value is $-\mathbf{2 , 2 5 5 . 2 8 5}$ indicating that if e-money, interest rates and money supply remain constant, inflation in Indonesia is $\mathbf{- 2 , 2 5 5 . 2 8 5}$.

b) Value unstandardized coefficients $\beta 1$ sebesar 0.1690 , suggesting that if there is an increase in $e$ money 1 percent, it will cause inflation in Indonesia to increase by 0.1690 assuming a fixed interest rate ( cateries paribus ). 
c) Value unstandardized coefficients $\beta 2$ at 1.2024, suggesting that if there is an increase in interest rates of 1 percent, it will cause inflation in Indonesia to increase by 1.2024 with the assumption that the money supply is fixed (cateries paribus).

d) Value unstandardized coefficients $\beta_{3}$ at 0.3666 , suggesting that if there is an increase in the money supply 1 percent, it will cause inflation in Indonesia to increase by 0.3666 with the assumption that e-money is fixed (cateries paribus).

b. t test (Partial)

a) The result of the estimation of the coefficient of the e-money variable is 0.1690 and is significant in prob. $0.6278>\alpha=0.05$. This means that partially e-money has a positive and insignificant effect on inflation in Indonesia. If there is an increase in e-money by 1 percent, then inflation in Indonesia will decrease significantly by 0.1690 percent. Conversely, if there is a 1 percent decrease in e-money, then inflation in Indonesia will increase significantly by 0.1690 percent in one year, cateries paribus. So the statement of the first hypothesis which states that partially non-cash payments have a significant effect on inflation in Indonesia, is rejected. This is by the research of Zunaitin, Niken \& Wahyu (2017) which concluded that $e$ money partially has no significant effect because payment transactions using e-money are not widely known by the Indonesian people. So that the use of e-money is less than the maximum compared to cash payments.

b) The result of the estimated coefficient of the interest rate variable is 1.2024 and is significant in prob. $0.1787>\alpha=0.05$. This means that partially interest rates have a positive and insignificant effect on inflation in Indonesia. If there is an increase in interest rates by 1 percent, then inflation in Indonesia will decrease significantly by 1.2024 percent. Conversely, if there is a decrease in interest rates by 1 percent, then inflation in Indonesia will increase significantly by 1.2024 percent in one year, cateries paribus. So the second hypothesis statement which states that partially interest rates have a significant effect on inflation in Indonesia, is rejected. This is by the research of Ningsih and Kristiyanti (2018) which states that interest rates partially have no effect on inflation in Indonesia because the process of transmitting interest rate monetary policy to aggregate demand has not been fully running properly.

c) The estimation result of the variable coefficient of the money supply is 0.3666 and is significant in prob. $0.3324>\alpha=0.05$. This means that partially the money supply has a positive and insignificant effect on inflation in Indonesia. If there is an increase in the money supply by 1 percent, then inflation in Indonesia will decrease insignificantly by 0.3666 percent. Conversely, if there is a decrease in the money supply by 1 percent, then inflation in Indonesia will increase insignificantly by 0.3666 percent in one year, cateries paribus. So the third hypothesis statement which states that partially the money supply has a significant effect on inflation in Indonesia, is rejected. This supports the research conducted by Mahendra (2016) which states that the money supply partially has no effect on inflation in Indonesia. This means that this is not by the existing theory. This could be due to differences in the amount of money in circulation used.

\section{c. F Test (Simultaneous)}

F test value obtained by $0.155069>\alpha=0.05$. So it can be stated simultaneously that non-cash payments, interest rates, and the money supply have a insignificant effect on inflation in Indonesia. So the fourth hypothesis statement which states that simultaneously non-cash payments, interest rates, and the money supply have a significant effect on inflation in Indonesia, is rejected.

\section{d. Coefficient of Determination $\left(R^{2}\right)$}

$\mathrm{R}^{2}$ of 0.4670 or $46.70 \%$, meaning that the variable e-money, interest rates and the money supply affect inflation in Indonesia amounted to $46.70 \%$, while the remaining $53.30 \%$ influenced by other external factors that support research. 


\section{e. Classic assumption test}

Autocorrelation Test, Total data $(\mathrm{n})=10 \mathrm{k}=3$ (number of independent variables). Obtained $\mathrm{dL}$ (lower limit) of 1.2138 and $\mathrm{dU}$ (upper limit) of 1.3487. For the value of $4-\mathrm{dL}=(4-1,2138)=2,7862$ and the value of $4-\mathrm{dU}=(4-1,6498)=2,3502$. To see the results of the dW table test calculations as follows:

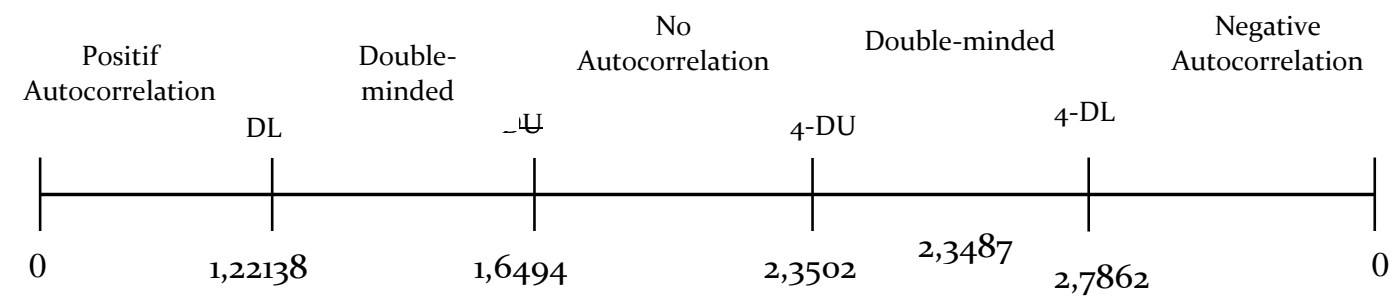

Based on the results of the Durbin-Watson calculation, the dW position is between 4-dU and 4-dL, so that in this model there is no conclusion or Double-minded.

Tabel 4. Multicollinearity Test

\begin{tabular}{cccc}
\hline \hline Variable & $\begin{array}{c}\text { Coefficient } \\
\text { Variance }\end{array}$ & $\begin{array}{c}\text { Uncentered } \\
\text { VIF }\end{array}$ & $\begin{array}{c}\text { Centered } \\
\text { VIF }\end{array}$ \\
\hline \hline C & 2.264836 & 207.0955 & NA \\
LOGX1 & 0.103967 & 179.1944 & 1.112023 \\
LOGX2 & 0.545147 & 150.5139 & 1.454779 \\
LOGX 3 & 0.110777 & 58.05959 & 1.331813 \\
\hline \hline
\end{tabular}

Source: Data processed with Eviews 10, 2021

From the results of the multicollinearity test above, it can be seen that the correlation value is $1.331813<10$ so it can be concluded that there is no multicollinearity problem or free from multicollinearity in this study.

Tabel 5. Heteroscedasticity Test

Heteroskedasticity Test: White

\begin{tabular}{lrll}
\hline \hline & & & \\
F-statistic & 0.112710 & Prob. F(3,4) & 0.948 \\
Obs*R-squared & 0.623548 & Prob. Chi-Square(3) & 0.8910 \\
Scaled explained SS & 0.079943 & Prob. Chi-Square(3) & 0.994 \\
\hline \hline
\end{tabular}

Test Equation:

Dependent Variable: RESID^2

Method: Least Squares

Date: 09/16/21 Time: 22:15

Sample: 20102019

Included observations: 8

\begin{tabular}{|c|c|c|c|c|}
\hline Variable & Coefficient & Std. Error & t-Statistic & Prob. \\
\hline C & 0.007494 & 0.151254 & 0.049545 & 0.9629 \\
\hline $\operatorname{LOGX}_{1}{ }^{\wedge}{ }_{2}$ & -0.001603 & 0.007274 & -0.220395 & 0.8364 \\
\hline $\operatorname{LOGX}_{2} \wedge_{2}$ & 0.016496 & 0.043461 & 0.379572 & 0.7236 \\
\hline $\operatorname{LOGX}_{3} \wedge_{2}$ & 0.002907 & 0.014695 & 0.197791 & 0.8529 \\
\hline
\end{tabular}




\begin{tabular}{lrlr} 
Adjusted R-squared & -0.613599 & S.D. dependent var & 0.047361 \\
S.E. of regression & 0.060162 & Akaike info criterion & -2.476710 \\
Sum squared resid & 0.014478 & Schwarz criterion & -2.436989 \\
Log likelihood & 13.90684 & Hannan-Quinn criter. & -2.744611 \\
F-statistic & 0.112710 & Durbin-Watson stat & 3.447204 \\
Prob(F-statistic) & 0.948143 & & \\
\hline \hline
\end{tabular}

Source: Data processed with Eviews 10, 2021

Based on the above estimation results obtained prob obs * R-Square by $0,8910>\alpha(0.05)$ then do not run into problems heteroskedastisitas.

Normality test,

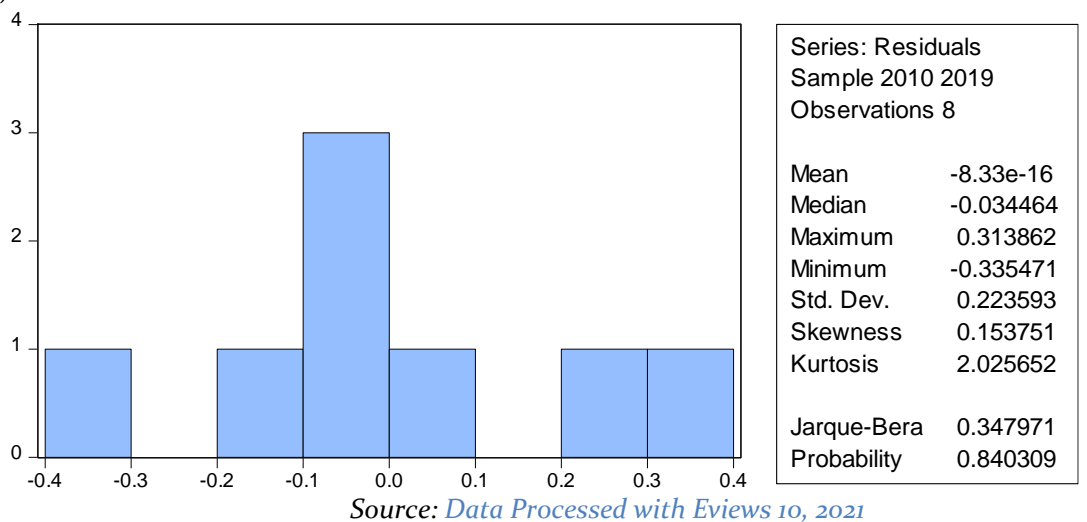

Figure 1. Grafik Normality test

Based on the results of the analysis above, the probability of Jarque Bera (JB) is 0.840309 > 0.05 , so the residuals are normally distributed.

\section{CONCLUSION}

The results of multiple linear regression equation $\mathrm{Y}=-\mathbf{2 . 2 5 5 . 2 8 5}+0,1690 \mathrm{X}_{1}+1,2024 \mathrm{X}_{2}+0,3666 \mathrm{X}_{3}$, equation results indicate that $e$-money, interest rates and the money supply had a positive influence on inflation in Indonesia., The results of the classical assumption test in the autocorrelation test obtained that the position of $\mathrm{dW}$ is between 4 - $\mathrm{dU}$ and 4 - $\mathrm{dL}$, so there is no conclusion or doubt. For multicollinearity test obtained $1.331813<10$ then there is no multicollinearity problem. As for the heteroscedasticity test obtained at $0.8910>\alpha=(0.05)$ then do not run into problems heteroskedastisitas. And for the normality test, the probability of Jarque Bera (JB) is $0.840309>0.05$, so it is normally distributed., $T$ test results in non-cash payments variables obtained at $0.6278>\alpha=$ 0.05 and no effect on inflation and rejected. The variable interest rate obtained was $0.1787>\alpha=0.05$ and an effect on inflation and rejected. And the variable supply of money obtained at $0.3324>\alpha=0.05$ and no effect on inflation, rejected., F-test is done by comparing the F significant and $\alpha=5 \%$, obtained by $0,155069<\alpha=0.05$. So it can be stated simultaneously that non-cash payments, interest rates, and the money supply have a insignificant effect on inflation in Indonesia., The results of the coefficient of determination test obtained a value of 0.4670 or $46.70 \%$, meaning that the variables of $e$-money, interest rates, and the money supply affect inflation in Indonesia by $46.70 \%$, while the remaining $53.30 \%$ is influenced by factors - other external factors outside this research.

\section{REFERENCES}

Abidin, M. S. (2015). Dampak Kebijakan E-Money Di Indonesia Sebagai Alat Sistem Pembayaran Baru. Jurnal Akuntansi UNESA, 3(2), 1-21.

Carl, M. S. (2017). Non-Cash Payment Transactions Processing in Indonesia. Retrieved December, 12, 2019.

Dagdemir, C., \& Sauer, J. (2015). The Use of Card Payment Instruments: A Panel Data Approach. 
Davenport, T. H., \& Short, J. E. (1990). The new industrial engineering: information technology and business process redesign.

Harasim, J. (2016). Europe: the shift from cash to non-cash transactions. In Transforming payment systems in Europe (pp. 28-69). Springer.

Hess, P. (2017). The ongoing evolution of payment instruments in China: A case study in financial innovation, and on the role of the central bank. In Cash in East Asia (pp. 117-131). Springer.

Lindsey, T. (2012). Between piety and prudence: State Syariah and the regulation of Islamic banking in Indonesia. Sydney Law Review, The, 34(1), 107-127.

Madani, A., \& Widiastuti, T. (2021). The Impact of Islamic Monetary Operations and Aggregate Financing on Economic Growth in Indonesia (2010-2020). JEBIS (Jurnal Ekonomi Dan Bisnis Islam)| JOURNAL OF ISLAMIC ECONOMICS AND BUSINESS, 7(2), 185-209.

Mentari, N. W., Setiawina, I. N. D., Budhi, I. M. K. S., \& Sudirman, I. W. (2019). Influence factor of consumers interest on using E-money. International Journal of Social Sciences and Humanities, 3(2), 176-186.

Mohammad, A. (2008). The Development of E-payments and Challenges in Malaysia. The Development of EPayments and Challenges for Central Banks in The SEACEN Countries.

Ningsih, S., \& Kristiyanti, L. M. S. (2019). Analisis Pengaruh Jumlah Uang Beredar, Suku Bunga dan Nilai Tukar terhadap Inflasi di Indonesia Periode 2014-2016. Jurnal Manajemen Dayasaing, 20(2), 96-103.

Popovska-Kamnar, N. (2014). The use of electronic money and its impact on monetary policy. Journal of Contemporary Economic and Business Issues, 1(2), 79-92.

Priyatama, A., \& Apriansah, A. (2010). Correlation between electronic money and the velocity of money. Global Management Conference.

Putra, G. A., Sabrie, H. Y., \& Thalib, P. (2017). The Product Characteristic of Electronic Money from the Perspective of the Negotiable Instruments Law. Jurnal FIAT JUSTISIA, 11 (4), 328-341.

Setiawati, C. I., \& Falah, N. (2019). E-Money Challenge in Disruption Era: Uncovering the Dilemma Issues from Consumers' Perspective. Sustainable Business and Society in Emerging Economies, 1(2), 109-122.

Shamraev, A. (2019). Legal and regulatory framework of the payment and e-money services in the BRiCS countries. BRICS Law Journal, 6(2), 6o-81.

Silitonga, T. (2013). Analisis Permintaan Uang Elektronik (E-Money) Terhadap Velocity Of Money (Perputaran Uang) Di Indonesia. Skripsi Si Universitas Sumatra Utara.

Snyder, H. (2019). Literature review as a research methodology: An overview and guidelines. Journal of Business Research, 104, 333-339.

Tellis, W. (1997). Application of a case study methodology. The Qualitative Report, 3(3), 1-19.

Vom Brocke, J., Simons, A., Riemer, K., Niehaves, B., Plattfaut, R., \& Cleven, A. (2015). Standing on the shoulders of giants: Challenges and recommendations of literature search in information systems research. Communications of the Association for Information Systems, 37(1), 9.

Widayat, W., Masudin, I., \& Satiti, N. R. (2020). E-Money payment: Customers' adopting factors and the implication for open innovation. Journal of Open Innovation: Technology, Market, and Complexity, 6(3), 57.

Widjaja, E. P. O. (2016). Non-cash payment options in Malaysia. Journal of Southeast Asian Economies, 398-412.

Williamson, G. D., \& Money-America's, G. E. (2006). Enhanced authentication in online banking. Citeseer.

Worthington, S., \& Edwards, V. (2000). Changes in payments markets, past, present and future: a comparison between Australia and the UK. International Journal of Bank Marketing.

Xena, P., \& Rahadi, R. A. (2019). Adoption of e-payment to support small medium enterprise payment system: A conceptualised model. International Journal of Accounting, 4(18), 32-41.

Zunaitin, E. (2017). Pengaruh E-money terhadap Inflasi di Indonesia. Jurnal Ekuilibrium, 1(1), 18-23. 